\title{
Forage Production on Important Rangeland Habitat Types in Western Montana
}

\author{
W.F. MUEGGLER AND W.L. STEWART
}

\section{Abstract}

Peak standing crop and its variability were evaluated over a 3-year period on 35 sites representing 13 important grassland and shrubland habitat types in western Montana. Average production ranged from slightly over $600 \mathrm{~kg} / \mathrm{ha}$ on the least productive habitat type to $2,900 \mathrm{~kg} / \mathrm{ha}$ on the most productive. Good sites seldom produced more than twice as much as poor sites within the same habitat type. Although as much as $2 \frac{1}{2}$ times more herbage was produced on a site during the high year than during the low year, the maximum yearly difference for all sites averaged only $1 \frac{1}{2}$ times greater. Variation of vegetation classes and factors contributing to production differences are discussed.

The potential of different rangeland sites for producing forage differs greatly in the highly varied environment of the northern Rocky Mountains (Fig. 1). These differences in forage production, coupled with observed differences in other range values and responses to management activities, have stimulated efforts to identify and classify rangeland units according to their inherent capabilities. Much of the recent thrust in wildland classification in the West has focused on the habitat type concept (Daubenmire 1968; Pfister 1976). A classification using this concept has been developed recently for the nonforested rangelands in the mountainous western third of Montana (Mueggler and Stewart 1980). Once such a classification has been developed, however, resource parameters related to the classification units need to be defined. Quantification of resource values is essential to land management planning. Forage, of course, is generally accepted as the principal product to be derived from much of our western rangelands.

Forage production on native rangelands in the West is noted for its variation from year to year because of yearly weather differences, and for its variation from place to place because of basic environmental differences. Knowledge of the average forageproducing capabilities of a given range type and of the fluctuations around this average caused by yearly weather variations is fundamental for planning long-term grazing capacities. The need for information about forage potentials and variability on western Montana rangeland habitat types prompted the cooperative study between the Forest Service's (Northern) Region 1 and the Intermountain Forest and Range Experiment Station, results of which are reported here.

\section{Methods}

Of the 29 grassland and shrubland habitat types that we described for western Montana (Mueggler and Stewart 1980), 13 of the most important were selected for evaluating peak standing crops. Importance was determined by the relative amount of land occupied by a given habitat type and by the potential value of the type for producing forage for livestock and, in some cases, for deer and elk. The habitat types selected for measurement are listed in Table 1 .

Authors are principal plant ecologist, Intermountain Forest and Range Experiment Station, USDA Forest Service, Ogden, Utah 84401, located at the Forestry Sciences Laboratory, Utah State University, Logan; and range scientist, Region 1, Forest Service, Missoula, Montana 59806.

Manuscript received November 16, 1979.

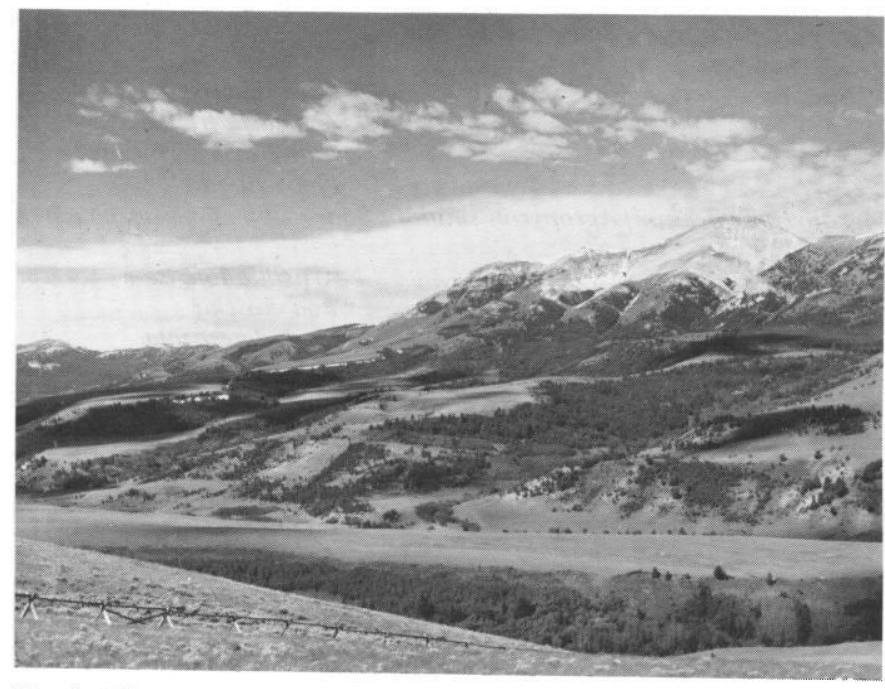

Fig. 1. The mountainous rangelands of western Montana vary greatly in their ability to produce livestock forage.

In most cases, the production level of each habitat type was evaluated by sampling 3 sites subjectively selected to represent the range in productivity for that habitat type; these sites were subsequently categorized as poor, intermediate, or good. The Agropyron spicatum/Agropyron smithii and Purshia tridentata/Festuca scabrella habitat types, however, are represented by only two sites each and the Deschampsia caespitosa/ Carex spp. h.t. is represented by only one site.

The selection of stands to span the range of site productivity within a habitat type was based initially upon species canopy-cover data collected during the development of our habitat-type classification for western Montana. From the numerous stands falling within a given habitat type, one was selected to represent each site productivity category (poor, intermediate, or good) on the basis of total canopy cover and the canopy cover of individual species. Each site was free from abusive grazing and occupied by littledisturbed native vegetation. We attempted to obtain wide geographical separation of the sites representing any one habitat type. In some cases, production differences subsequently measured between the intermediate and poor or intermediate and good categories were not great; however, we believe that the differences in production between the poor and good sites reflect fairly well the range in productivity usually encountered in a given habitat type.

The locations of the 35 sampled sites scattered through western Montana are shown in Figure 2. Site numbers refer to a given habitat type in Table 1.

Although the major plant species on different undisturbed sites within a habitat type are generally the same, secondary species may differ. The habitat type name usually consists of the two primary producers in climax communities of the habitat type. The four most abundant secondary species present on each site are shown in Table 1. The selection of these secondary species is based upon canopy cover and does not necessarily reflect relative biomass. For example, although low mat-forming plants such as Antennaria 
Table 1. Habitat types sampled, site number (refer to location, Fig. 1), productivity classification, and prominent species ${ }^{1}$ on each site in addition to those indicated by the habitat type name.

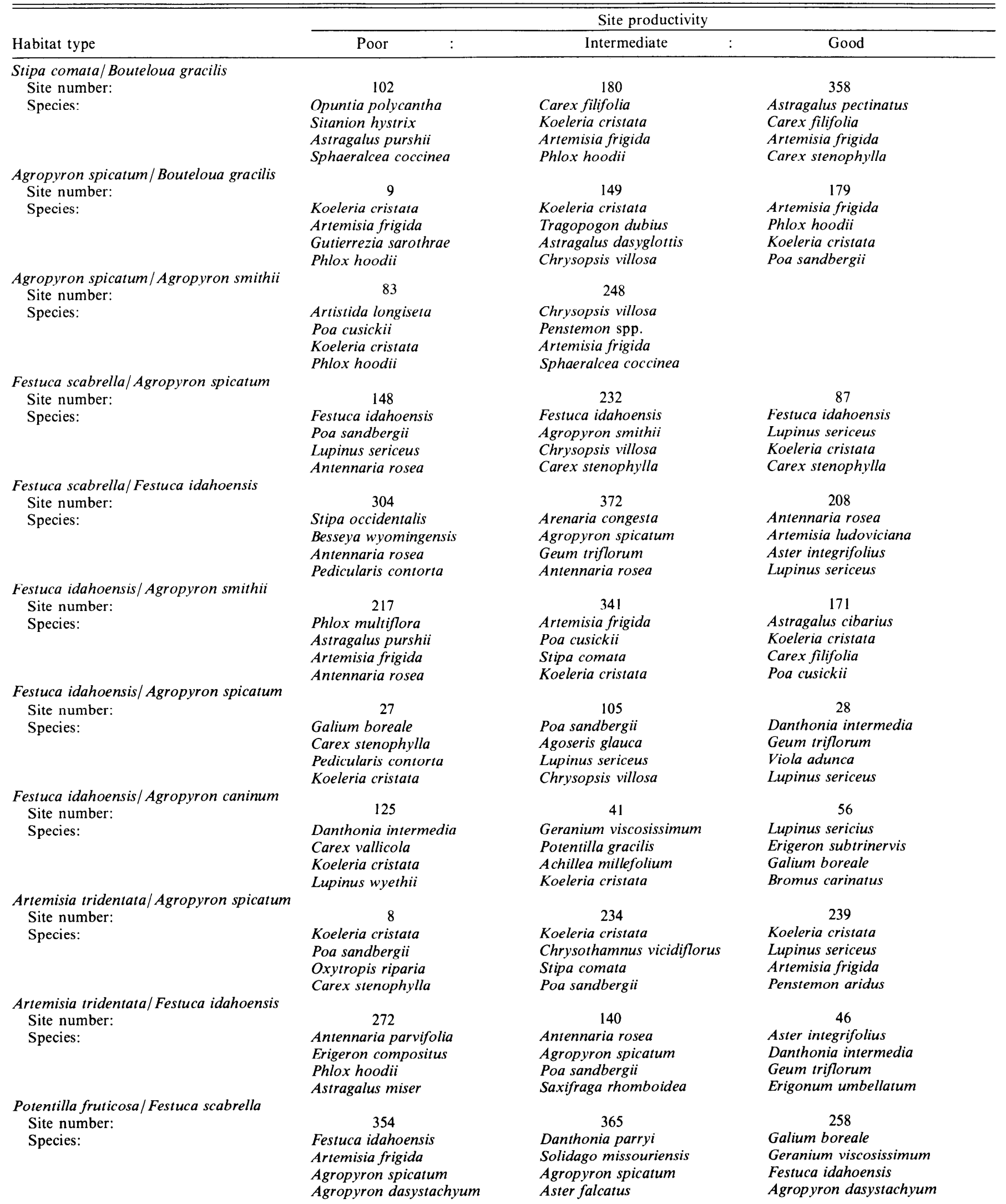


Purshia tridentata/Festuca scabrella Site number:

Species:

\section{Deschampsia caespitosa/Carex $\mathrm{spp}$ Site number:} Species:

\section{6}

Agropyron spicatum Bromus tectorum Balsamorhiza sagittata Poa sandbergii
306

Festuca idahoensis Balsamorhiza sagittata Agropyron spicatum Bromus tectorum
371

Carex athrostachya

Juncus balticus

Phleum alpinum

Aster integrifolius
In decreasing order of abundance as judged by canopy cover.

rosea and Phlox hoodii may have sufficient canopy cover to occur among the more abundant secondary species, they may produce considerably less biomass than the taller grasses and forbs with less canopy cover that are not listed among the four secondary species. A detailed listing of species likely to occur within each habitat type is given by Mueggler and Stewart (1980).

Standing crop on 33 of the 35 sites was measured in three consecutive years: 1974, 1975, and 1976. Production on the poor site in the Festuca idahoensis/Agropyron caninum h.t. (site 125) was measured only in 1974 and 1975, and that of the Deschampsia caespitosa/Carex spp. h.t. (site 371) was measured only in 1976. Though incomplete, data from the two sites provide productivity information not otherwise available for these important habitat types.

We attempted to schedule productivity measurements on each site at the time of peak standing crop. This meant that the carlier developing, low-elevation, and drier sites representing the Stipa comata/Bouteloua gracilis h.t. and Agropyron spicatum/Bouteloua gracilis h.t. were measured about mid-June. Later developing sites, such as those in the Festuca scabrella/Agropyron spicatum h.t., Purshia tridentata/Festuca scabrella h.t., and Artemisia tridentata/Agropyron spicatum h.t., were measured from early to mid-July; and still later developing sites, such as those in the Festuca scabrella / Festuca idahoensis h.t., Festuca idahoensis/A-

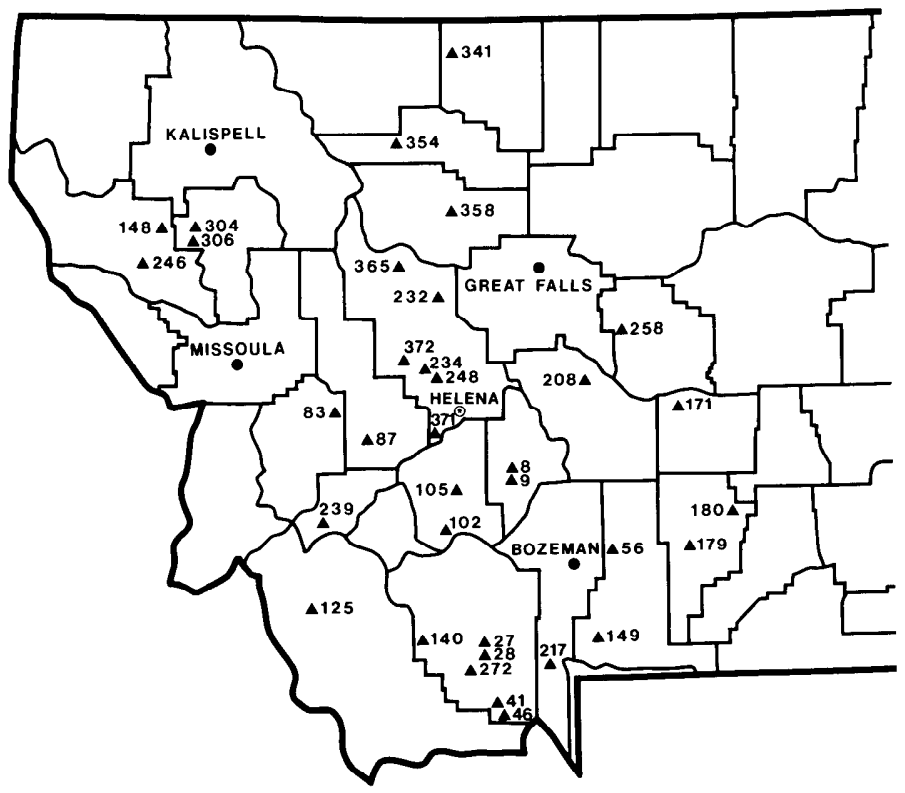

Fig. 2. Thirty-five sites in western Montana where herbage production was measured for three consecutive years. Site numbers are referenced to a given habitat type in Table 1. gropyron smithii h.t., and Artemisia tridentata/Festuca idahoensis h.t., were measured in late July or early August. The latest developing sites in the Festuca idahoensis/Agropyron caninum h.t. and Deschampsia caespitosa/Carex spp. h.t. were usually measured in early or mid-August. The logistical limitations of a single two-person sampling crew accessing sites scattered over an area as large as the mountainous western third of Montana prevented perfect coincidence of measurement time and peak standing crop; however, errors caused by slightly early or slightly late measurements were probably small.

Production on each site was measured from a randomized distribution of 10 clusters of five plots each on a $20 \times 20 \mathrm{~m}$ area subjectively selected to typify the site. Each plot was circular and covered $0.45 \mathrm{~m}^{2}$. The five plots in each cluster were located within easy view of one a nother on grid lines $1 \mathrm{~m}$ apart. Since one of the purposes of the study was to evaluate yearly variation in production attributable to weather, the use of permanent plots was desirable to reduce sampling error caused by spatial variability in the vegetation. One of the more valid techniques for assessing production is by clipping maximum aboveground standing crop. Clipping is destructive, however, affects production in subsequent years, and thus is not suited to permanent plot measurements. Therefore, we used a 1:4 ratio of clipped to estimated plots, of which the clipped plots were different each year and the estimated plots were permanent.

Production on each of the four permanent plots within a cluster was estimated as a percentage of the fifth plot, which was then clipped to ground level. All current-year growth of the clipped vegetation was sacked and later ovendried at $60^{\circ} \mathrm{C}$ to a constant weight for subsequent expression as $\mathrm{kg} /$ ha dry matter. Estimated percentages of the permanent plots were then converted to weight, thus providing weight data from five plots per cluster, or 50 plots per site. Data were recorded scparately for the major plant classes: graminoids, forbs plus half-shrubs, and woody shrubs. Data were also recorded separately for the usually few major species that together comprised approximately three-fourths of the total standing crop on a site. Wherever livestock used on a site prior to production measurement was a possibility, the plots to be clipped were protected by utilization cages and the estimates from the permanent plots were adjusted to herbage utilization. Production determinations from 50 plots were judged adequate to achieve a sampling precision of within $\pm 10 \%$ of the population mean for total herbage and for total graminoid production, but only within $\pm 35 \%$ for total forbs, all at the $90 \%$ probability level (Mueggler 1976). Sampling error for forbs increased as forb production decreased and forb distribution became more erratic. This type of sampling error relates only to comparisons between sites and not to comparisons between years, because comparisons between years are based primarily on permanent plot records.

To facilitatc usc of this production information by range managers, we partitioned the data into forage and nonforage categories. 
Table 2. Peak standing crop (dry $\mathrm{kg} / \mathrm{ha}$ for important rangeland habitat types in western Montana averaged over a 3-year period with the limits of variation expected in 8 out of 10 years.

\begin{tabular}{|c|c|c|c|c|c|c|c|c|c|}
\hline \multirow[b]{3}{*}{ Habitat type } & \multicolumn{9}{|c|}{ Site productivity } \\
\hline & \multicolumn{3}{|c|}{ Poor } & \multicolumn{3}{|c|}{ Intermediate } & \multicolumn{3}{|c|}{ Good } \\
\hline & $\begin{array}{r}\text { Average } \\
\text { production }\end{array}$ & $\begin{array}{r}\text { Yearly } \\
\text { variability }\end{array}$ & $\begin{array}{r}\text { Percent } \\
\text { forage }\end{array}$ & $\begin{array}{r}\text { Average } \\
\text { production }\end{array}$ & $\begin{array}{r}\text { Yearly } \\
\text { variability }\end{array}$ & $\begin{array}{r}\text { Percent } \\
\text { forage }\end{array}$ & $\begin{array}{r}\text { Average } \\
\text { production }\end{array}$ & $\begin{array}{r}\text { Yearly } \\
\text { variability }\end{array}$ & $\begin{array}{r}\text { Percent } \\
\text { forage }\end{array}$ \\
\hline \multicolumn{10}{|l|}{ Stipa comatal } \\
\hline Graminoids & 263 & \pm 126 & 100 & 351 & \pm 118 & 100 & 783 & \pm 188 & 100 \\
\hline Forbs & 7 & \pm 9 & 0 & 436 & \pm 117 & 19 & 166 & \pm 95 & 14 \\
\hline Shrubs & 0 & - & - & 0 & - & - & 0 & - & $\ldots$ \\
\hline Total & 270 & \pm 119 & 98 & 787 & \pm 234 & 55 & 949 & \pm 271 & 85 \\
\hline \multicolumn{10}{|c|}{ Agropyron spicatum/ } \\
\hline Graminoids & 272 & \pm 50 & 100 & 240 & \pm 109 & 100 & 523 & \pm 100 & 100 \\
\hline Forbs & 213 & \pm 53 & 0 & 248 & \pm 30 & 32 & 343 & \pm 177 & 17 \\
\hline Shrubs & 0 & - & - & 0 & - & - & 0 & - & - \\
\hline Total & 485 & +100 & 56 & 488 & \pm 82 & 65 & 866 & \pm 269 & 67 \\
\hline \multicolumn{10}{|c|}{ Agropyron spicatum/ } \\
\hline \multicolumn{10}{|c|}{ Agropyron smithii } \\
\hline Graminoids & 538 & \pm 134 & 100 & 832 & \pm 226 & 100 & - & - & 一 \\
\hline Forbs & 214 & \pm 114 & 0 & 67 & +44 & 20 & - & - & - \\
\hline Shrubs & 2 & \pm 3 & 0 & 0 & - & - & - & - & - \\
\hline Total & 754 & \pm 201 & 72 & 899 & \pm 245 & 94 & - & - & - \\
\hline $\begin{array}{l}\text { Festuca scabrel } \\
\text { Agropyron spic }\end{array}$ & & & & & & & & & \\
\hline Graminoids & 757 & \pm 104 & 100 & 888 & \pm 198 & 100 & 888 & \pm 409 & 100 \\
\hline Forbs & 142 & \pm 129 & 15 & 109 & \pm 22 & 13 & 442 & \pm 194 & 0 \\
\hline Shrubs & 0 & - & - & 0 & - & - & 17 & \pm 8 & 0 \\
\hline Total & 899 & \pm 85 & 87 & 997 & \pm 177 & 91 & 1347 & \pm 610 & 66 \\
\hline Festuca scabrel & & & & & & & & & \\
\hline Festuca idahoe & & & & & & & & & \\
\hline Graminoids & 934 & \pm 10 & 100 & 1097 & \pm 86 & 100 & 1692 & \pm 655 & 100 \\
\hline Forbs & 268 & \pm 221 & 2 & 500 & \pm 105 & 8 & 136 & \pm 36 & 0 \\
\hline Shrubs & 0 & - & - & 0 & - & - & 0 & - & - \\
\hline Total & 1202 & \pm 231 & 75 & 1597 & \pm 59 & 71 & 1828 & \pm 745 & 93 \\
\hline Festuca idahoe & & & & & & & & & \\
\hline Agropyron smi & & & & & & & & & \\
\hline Graminoids & 397 & \pm 50 & 100 & 985 & \pm 386 & 100 & 1253 & \pm 128 & 100 \\
\hline Forbs & 386 & \pm 228 & 22 & 21 & \pm 12 & 0 & 195 & \pm 150 & 50 \\
\hline Shrubs & 24 & \pm 19 & 0 & 0 & - & - & 0 & - & - \\
\hline Total & 807 & \pm 229 & 60 & 1006 & \pm 397 & 98 & 1448 & \pm 227 & 93 \\
\hline Festuca idahoe & & & & & & & & & \\
\hline Agropyron $s$ & & & & & & & & & \\
\hline Graminoids & 304 & \pm 45 & 100 & 583 & \pm 18 & 100 & 521 & \pm 193 & 100 \\
\hline Forbs & 432 & \pm 110 & 20 & 247 & \pm 98 & 30 & 927 & \pm 226 & 14 \\
\hline Shrubs & 0 & - & - & 4 & \pm 4 & 100 & 0 & - & - \\
\hline Total & 736 & \pm 155 & 53 & 834 & \pm 112 & 79 & 1448 & \pm 367 & 45 \\
\hline Festuca idahoe & & & & & & & & & \\
\hline Agropyron can & & & & & & & & & \\
\hline Graminoids & 412 & -1 & .100 & 750 & \pm 240 & 96 & 1017 & \pm 203 & 100 \\
\hline Forbs & 925 & - & 14 & 976 & \pm 492 & 33 & 847 & \pm 186 & 14 \\
\hline Shrubs & 0 & - & - & 0 & - & - & 0 & & $\underline{-14}$ \\
\hline Total & 1337 & - & 41 & 1726 & \pm 727 & 61 & 1864 & \pm 288 & 60 \\
\hline Deschampsia ca & & & & & & & & & \\
\hline Carex spp. & & & & & & & & & \\
\hline Graminoids & - & - & - & 2877 & -2 & 100 & - & - & - \\
\hline Forbs & - & - & - & 33 & - & 0 & - & - & - \\
\hline Shrubs & - & - & - & 0 & - & - & - & - & - \\
\hline Total & - & - & - & 2910 & - & 99 & - & - & - \\
\hline Artemisia tride & & & & & & & & & \\
\hline Agropyron spic & & & & & & & & & \\
\hline Graminoids & 312 & \pm 101 & 100 & 411 & \pm 142 & 100 & 479 & \pm 84 & 100 \\
\hline Forbs & 149 & \pm 35 & 13 & 57 & \pm 30 & 0 & 259 & \pm 22 & 0 \\
\hline Shrubs & 374 & \pm 67 & 0 & 374 & \pm 74 & 1 & 238 & \pm 29 & 0 \\
\hline Total & 835 & \pm 145 & 40 & 842 & \pm 56 & 49 & 976 & \pm 80 & 49 \\
\hline Artemisia tride & & & & & & & & & \\
\hline Festuca idahoe & & & & & & & & & \\
\hline Graminoids & \pm 225 & \pm 26 & 100 & 259 & \pm 16 & 100 & 683 & \pm 71 & 100 \\
\hline Forbs & 474 & \pm 177 & 13 & 457 & \pm 65 & 6 & 774 & \pm 112 & 11 \\
\hline Shrubs & 156 & \pm 57 & 1 & 492 & \pm 85 & 0 & 161 & \pm 57 & 0 \\
\hline Total & 855 & \pm 219 & 34 & 1208 & \pm 104 & 24 & 1618 & \pm 93 & 48 \\
\hline
\end{tabular}




\begin{tabular}{|c|c|c|c|c|c|c|c|c|c|}
\hline \multirow[b]{3}{*}{ Habitat type } & \multirow{2}{*}{\multicolumn{3}{|c|}{ Poor }} & \multicolumn{3}{|c|}{ Site productivity } & \multirow{2}{*}{\multicolumn{3}{|c|}{ Good }} \\
\hline & & & & \multicolumn{3}{|c|}{ Intermediate } & & & \\
\hline & $\begin{array}{r}\text { Average } \\
\text { production }\end{array}$ & $\begin{array}{r}\text { Yearly } \\
\text { variability }\end{array}$ & $\begin{array}{r}\text { Percent } \\
\text { forage }\end{array}$ & $\begin{array}{r}\text { Average } \\
\text { production }\end{array}$ & $\begin{array}{r}\text { Yearly } \\
\text { variability }\end{array}$ & $\begin{array}{r}\text { Percent } \\
\text { forage } \\
\end{array}$ & $\begin{array}{r}\text { Average } \\
\text { production }\end{array}$ & $\begin{array}{r}\text { Yearly } \\
\text { variability }\end{array}$ & $\begin{array}{r}\text { Percent } \\
\text { forage } \\
\end{array}$ \\
\hline \multicolumn{10}{|c|}{$\begin{array}{l}\text { Potentilla fruticosa/ } \\
\text { Festuca scabrella }\end{array}$} \\
\hline Graminoids & 758 & \pm 206 & 100 & 929 & \pm 314 & 100 & 1295 & \pm 291 & 100 \\
\hline Forbs & 217 & \pm 123 & 12 & 312 & +124 & 2 & 502 & \pm 194 & 31 \\
\hline Shrubs & 56 & \pm 27 & 0 & 48 & \pm 49 & 0 & 189 & \pm 134 & 22 \\
\hline Total & 1031 & \pm 333 & 76 & 1289 & \pm 464 & 73 & 1986 & \pm 574 & 75 \\
\hline \multicolumn{10}{|c|}{$\begin{array}{l}\text { Purshia tridentata/ } \\
\text { Festuca scabrella }\end{array}$} \\
\hline Graminoids & 456 & \pm 242 & 100 & - & - & - & 483 & \pm 86 & 100 \\
\hline Forbs & 425 & \pm 188 & 88 & - & - & - & 607 & \pm 308 & 81 \\
\hline Shrubs & 123 & \pm 109 & 100 & - & - & - & 298 & \pm 139 & 99 \\
\hline Total & 1004 & \pm 529 & 95 & - & - & - & 1388 & \pm 369 & 91 \\
\hline
\end{tabular}

Only 2 years of data available.

2Only 1 year of data available.

A species was considered a forage contributor if it rated fair or better in palatability to sheep and/or cattle. The palatability ratings were obtained from Mueggler and Stewart (1980). Weight data on a site for those species that were not measured separately (approximately 25\% of the biomass) were inferred from the species' relative canopy cover that was available from a previous study.

\section{Results and Discussion}

\section{Variation between Habitat Types}

A 10-fold difference in annual aboveground standing crop was encountered among these 35 rangeland sites in western Montana. Production ranged from $270 \mathrm{~kg} /$ ha on the poor Stipa comata/ Bouteloua gracilis site to $2,910 \mathrm{~kg} / \mathrm{ha}$ on the Deschampsia caespitosa/Carex spp. site (Table 2). Practically all vegetation on these two extreme sites consisted of forage species.

The habitat types were ranked according to overall productivity by averaging the data for the different sites within habitat types over the 3-year sampling period. In most cases, the resulting production figure for a habitat type represents a nine-sample mean. This ranking showed that the most productive habitat type averaged almost five times more total herbage than the least productive habitat type:

\section{Habitat type}

Agropyron spicatum/Bouteloua gracilis

Stipa comata/Bouteloua gracilis

Agropyron spicatum/Agropyron smithii

Artemisia tridentata/Agropyron spicatum

Festuca idahoensis/Agropyron spicatum

Festuca scabrella/Agropyron spicatum

Festuca idahoensis/Agropyron smithii

Purshia tridentata/Festuca scabrella

Artemisia tridentata/Festuca idahoensis

Potentilla fruticosa/Festuca scabrella

Festuca scabrella/Festuca idahoensis

Festuca idahoensis/Agropyron caninum

Deschampsia caespitosa/Carex spp.

\section{Total standing crop (kg/ha)}

613
669
832
884
1006
1082
1087
1197
1227
1436
1562
1646
2910

Total standing crop in these natural communities does not coincide necessarily with their value for producing livestock forage. The relative amount of standing crop consisting of forage species ranged from about $40 \%$ of the Artemisia tridentata-dominated sites to $99 \%$ on the Deschampsia caespitosa/Carex spp. h.t. (Table 2). Usually the shrub sites (excluding those dominated by Purshia tridentata) and those herblands with high proportions of forbs had the greatest percentage of production consisting of nonforage plants. A ranking of the habitat types according to total produc- tion of forage plants indicated that the most productive habitat type was seven times more valuable as livestock range than the least productive habitat type:

\section{Habitat type}

Standing Crop of
forage species
$(\mathrm{kg} / \mathrm{ha})$

Agropyron spicatum/Bouteloua gracilis Artemisia tridentata/Agropyron spicatum Artemisia tridentata/Festuca idahoensis Stipa comata/Bouteloua gracilis

Festuca idahoensis/Agropyron spicatum Agropyron spicatum/Agropyron smithii Festuca scabrella/Agropyron spicatum Festuca idahoensis/Agropyron caninum Festuca idahoensis/Agropyron smithii

Potentilla fruticosa/Festuca scabrella

Purshia tridentata/Festuca scabrella

Festuca scabrella/Festuca idahoensis

Deschampsia caespitosa/Carex spp.
These herbage production figures, however, are not equivalent to the amount of feed available for use by livestock. The figures must be discounted to what is considered proper use, which is contingent primarily upon plant requirements for maintaining vigor. Requirements vary for different forage species and season of use. Effects of use are reviewed in general by Ellison (1960) and Jameson (1963), and as related directly to these habitat types by Mueggler and Stewart (1980). Seldom is more than 50\% use of key species considered wise under season-long grazing. A greater proportion of the total production of forage species might be removed without long-term ill effects under fall grazing or under such a specialized grazing system as rest-rotation.

Munn et al. (1978) examined eight of these habitat types to determine environmental factors that might be related to differences in productivity. They identified 18 variables significantly related to total standing crop and concluded that soil morphological characteristics are more useful predictors of productivity than either estimated climatic data or soil nutrient data. The thickness of the mollic epipedon (the relativcly thick, dark surface horizon of mineral soil) was most highly correlated $(r=0.73)$ with productivity. They indicated that productivity generally increased along an increasing moisture gradient and found significant correlation $(r=0.59)$ between estimated annual precipitation and total production.

We examined the relationship between estimated average precipitation and standing crop on 12 of the 13 habitat types for which we had production data. The Deschampsia caespitosa/Carex spp. h.t. was omitted because it typically occurs in mountain meadows subject to spring flooding or subirrigation. The long-term precipi- 
tation average for each site was first estimated from isohyetal maps of western Montana (Ross and Hunter 1976). Average precipitation on each site for the 1974-1976 period was then determined by adjusting the isohyetal figure according to the yearly departure from normal during this period of the permanent weather station (U.S. Weather Bureau, 1973-1976) closest to each sitc. Thc adjusted precipitation for the three sites within a habitat type was then averaged to obtain a mean precipitation value for the habitat type for the 1974-1976 study period. We found that the average production for each of the 12 habitat types was significantly correlated $(r=0.73)$ with the average October through September precipitation for the 3-year period.

\section{Variation within Habitat Types}

Individual plant species are known to cxhibit tolerance to certain variations in environmental conditions. Some species, e.g., certain Astragalus, are rather site specific. Others, e.g. Festuca idahoensis, can grow under a fairly wide range of environmental conditions; in other words, they have broad ecological amplitude. A species' ecological amplitude is governed by phenotypic plasticity and by the genetic diversity within the species' classification unit, which in turn is sometimes dependent upon rather arbitrary classification criteria. The same phenomenon occurs with plant communities or, in this case, habitat type classification units. The environmental specificity of a habitat type is governed in part by the ecological amplitude of its defining species; it is also strongly influenced by the a mount of diversity in secondary species arbitrarily permitted in development of the vegetation classification unit. Thus a given habitat type can occupy a restricted range of environmental conditions.

By purposefully selecting what we intended would represent poor and good site conditions within a given habitat type, we obtained an approximation of the variability in herbage production likely to be encountered within the environmental range of the type. The poor-site versus good-site differences in production shown in Table 2 are 3-year means, thus minimizing production differences between sites that might be caused by yearly weather variations.

Less than twice as much total standing crop was produced on the good than on the poor sites in all but one habitat type. The Stipa comata/Bouteloua gracilis h.t., one of the least productive grasslands in western Montana, produced over three times as much vegetation on the good than on the poor site. Within habitat type variability in production by vegetation class was substantially greater than that for total vegetation. Generally from two to three times as many graminoids and frequently over three times as many forbs were produced on the good site as on the poor sites. Differences in production of individual species often were even greater. Thus, total production was generally least variable, graminoid production next, and forb production most variable between sites within a habitat type.

We found that the difference in a mount of forage plants between these relatively undisturbed sites within habitat types was only slightly greater than the one and one-half to two time difference found in total vegetation. We would expect, however, the proportion of forage plants on a site to decrease appreciably under abusive grazing. This would probably result in substantially greater within-type variation of forage production than of total production when various range condition classes are involved.

We believe that the amount of soil water available for plant growth is the primary factor affecting both within-type production differences and production differences between habitat types. Available soil water is a function of precipitation, soil depth for water storage, and those factors affecting water loss by evapotranspiration. We were unable, however, to demonstrate statistically a relationship between production within habitat types and either precipitation or soil depth bccausc of inadequatc data for cach type.

\section{Variation between Years}

We obtained an estimate of the influence of yearly weather differences on herbage production by sampling each site over a 3 -year period. From the amount of variation in production encountered during this period, we computed the production limits likely to occur in 8 out of 10 years - the yearly variability data presented in Table 2.

Over this particular 3-year period total standing crop on one site during the high year was as much as $2 \frac{1}{2}$ times greater than during the low year, but over all sites averaged only about $1-1 / 2$ times greater. The coefficient of variation in total standing crop ranged from about 5 to $40 \%$ and averaged $22 \%$. There was no pronounced difference between either habitat types nor between good or poor sites in the proportionate amount of yearly variability in total standing crop.

Standing crop of total graminoids varied about the samc amount from year to year as total vegetation. The greatest variation was a difference of about $2 \frac{1}{2}$ times on one site. Graminoid production on all sites averaged 1.6 times greater during a high production year than during a low production year. The range and average coefficient of variation for yearly variability of graminoid production was essentially the same as that for total standing crop. No relationship was apparent between the relative amount of variability and either habitat type or site quality.

The standing crop of total forbs varied about twice as much from year to year as the graminoids. The amount of variation appeared to be related to the quantity of forbs in the community. Forb production over all sites averaged 2.6 times more during a high production year than during a low production year. Where forbs made up less than $20 \%$ of the total biomass, production increased an average 3.7 times compared to an average 2.0 times where forbs made up more than $20 \%$ of the biomass. The coefficient of variation for the former sites ranged from approximately 50 to $100 \%$ and for the latter sites, from 10 to $50 \%$.

Yearly variation in annual shrub production was similar to that

Table 3. Comparison of peak standing crop (dry kg/ha) between a 3-year and a 10-year period on two sites in the Festuca idahoensis/Agropyron spicatum habitat type.

\begin{tabular}{|c|c|c|c|c|c|c|}
\hline \multirow[b]{2}{*}{ Item } & \multicolumn{3}{|c|}{ Ten-year record (1964-1973) } & \multicolumn{3}{|c|}{ Three-year record (1974-1976) } \\
\hline & $\begin{array}{r}\text { Range in } \\
\text { production }\end{array}$ & $\begin{array}{r}\text { Average } \\
\text { production }\end{array}$ & $\begin{array}{r}\text { Yearly } \\
\text { variability! } \\
\end{array}$ & $\begin{array}{r}\text { Range in } \\
\text { production }\end{array}$ & $\begin{array}{r}\text { Average } \\
\text { production }\end{array}$ & $\begin{array}{r}\text { Yearly } \\
\text { variability }\end{array}$ \\
\hline \multicolumn{7}{|c|}{ Site 27} \\
\hline Graminoids & $270-586$ & 407 & \pm 44 & $256-332$ & 304 & \pm 45 \\
\hline Forbs & $276-421$ & 359 & \pm 22 & $316-502$ & 432 & \pm 110 \\
\hline Total & $661-917$ & 766 & \pm 41 & $572-825$ & 736 & \pm 155 \\
\hline \multicolumn{7}{|c|}{ Site 28} \\
\hline Graminoids & $228-628$ & 446 & \pm 49 & $352-706$ & 521 & \pm 193 \\
\hline Forbs & $583-1451$ & 1024 & \pm 94 & $708-1123$ & 927 & \pm 226 \\
\hline Total & $811-1774$ & 1470 & \pm 119 & $1061-1657$ & 1448 & \pm 367 \\
\hline
\end{tabular}

'Limits of variation expected in 8 out of 10 years. 
of the forbs. When all sites were averaged, current annual production of shrubs was 2.8 times greater during a high production year as during a low production ycar. Where shrubs made up less than $20 \%$ of the total biomass, four times more was produced during the high than during the low year. Where shrubs constituted more than $20 \%$ of the total biomass, shrub production was only 1.6 times greater on the average. The coefficient of variation in early shrub production ranged from about 30 to $90 \%$ for those sites with less than $20 \%$ shrubs and from about 10 to $40 \%$ for those sites with more than $20 \%$ shrubs.

How representative of long-term variability is the 3-year period covered by this study? October through September precipitation records from U.S. Weather Bureau stations closest to the sites indicate that the 1974 through 1976 period average $15 \%$ wetter than the long-term averages. The wettest year of the 3-year period averaged approximately $35 \%$ more precipitation and the driest year approximately $15 \%$ less than the long-term averages.

How typical the 3-year standing crop data are of a longer period of time is indicated by a comparison with similar data obtained over 10 years on site 27 and 28 in the Festuca idahoensis/Agropyron spicatum h.t. (Table 3 ). The 10 -year records were collected from 1964 to 1973 near the plots used for the 3-year records. Sampling intensity and methods were similar for both periods. Part of the difference in average production between the two periods can be attributed to the difference in placement of the sample plots. Therefore, variability contrasts are more easily understood when expressed as proportions of mean production.

The proportionate range in production of total vegetation on site 27 , a poor site, was approximately the same for the short- and long-term records. The difference in total production between the high and low years amounted to approximately one-third of the production mean. Although the proportionate range in production of total forbs was also approximately the same for the two periods, the 3-year period poorly represented the long-term range in production of total graminoids. On site 28 , which is considered a highly productive site in this habitat type, the proportionate range in production of total vegetation from the long-term record was grcater $(66 \%$ of the mean) than from the short-term record $(41 \%$ of the mean). Similar differences in proportionate ranges occurred for the two vegetation classes. This suggests that although the 3-year records may be fairly representative of the long-term variability in total standing crop on poor sites, they may be conservative in portraying long-term variability on good sites. The computed ranges in variability for 8 out of 10 years shown in Table 3 are appreciably greater for the 3-year than for the 10 -year record because of the difference in number of sample years.

\section{Literature Cited}

Daubenmire, R. 1968. Plant Communities, a Textbook of Plant Synecology. Harper and Row, New York, 300 p.

Ellison, L. 1960. Influence of grazing on plant succession of rangelands. Bot. Rev. 26:1-78.

Jameson, D.A. 1963. Response of individual plants to harvesting. Bot. Rev. 29:532-594.

Mueggler, W.F. 1976. Number of plots required for measuring productivity on mountain grasslands in Montana. USDA Forest Serv. Res. Note INT-207, $6 \mathrm{p}$

Mueggler, W.F., and W.L. Stewart. 1980. Grassland and shrubland habitat types of western Montana. U.S. Dep. Agr. Forest Service Gen. Tech. Rep. INT-66, $154 \mathrm{p}$.

Munn, L.C., G.A. Nielsen, and W.F. Mueggler. 1978. Relationship of soils to mountain and foothill range habitat types and production in western Montana. Soil Sci. Soc. Amer. J. 42:135-139.

Pfister, R.D. 1976. Land capability assessment by habitat types. Proc. 1975 Natl. Conserv. Soc. Amer. Forest 1976: 312-325.

Ross, R.L., and H.E. Hunter. 1976. Climax vegetation of Montana based on soils and climate. U.S. Dep. Agr. Soil Conserv. Service, Bozeman, Mont. 64 p. (processed).

U.S. Weather Bureau. 1973-1976. Climatological data: Montana section. U.S. Dept. of Commerce, NOAA, Washington, D.C. 